\title{
Penyebab Penyakit Layu pada Tanaman Semangka di Karawang, Jawa Barat
}

\author{
Causal Agents of Wilting Disease on Watermelon \\ in Karawang, West Java
}

\author{
Kartini Budiastuti, Efi Toding Tondok*, Suryo Wiyono \\ Institut Pertanian Bogor, Bogor 16680
}

\begin{abstract}
ABSTRAK
Penyakit layu sudah menjadi penyakit penting pada pertanaman semangka di berbagai daerah di Indonesia, tetapi belum ada penelitian khusus tentang penyebab penyakit tersebut. Upaya identifikasi penyebab penyakit layu pada tanaman semangka dilakukan mengikuti tahapan Postulat Koch. Tanaman semangka bergejala layu dikumpulkan dari daerah Karawang, Jawa Barat. Isolasi cendawan dilakukan dari bagian akar dan batang tanaman, identifikasi isolat murni didasarkan karakter morfologi. Uji patogenisitas cendawan kandidat dilakukan menggunakan 2 metode, yaitu menggunakan media tanah dan kertas merang. Uji kisaran inang dilakukan menggunakan tanaman Cucurbitaceae lainnya yaitu melon, mentimun, dan paria. Tiga spesies cendawan Fusarium berhasil diisolasi dari tanaman semangka yang bergejala layu, yaitu $F$. oxysporum, F. solani, dan F. semitectum. Diantara ketiga cendawan tersebut, $F$. oxysporum secara konsisten menyebabkan layu yang parah pada tanaman semangka tetapi tidak menimbulkan gejala penyakit pada tanaman melon, mentimun, dan paria. Dua spesies lainnya, $F$. solani dan F. semitectum, juga menyebabkan layu pada semangka dengan cara menyebabkan nekrotik pada akar dan batang, namun gejalanya berbeda dengan gejala awal saat tanaman sakit diambil dari lapangan. Oleh karena itu, penyebab penyakit layu pada semangka disimpulkan sebagai $F$. oxysporum f.sp. niveum.
\end{abstract}

Kata kunci: Cucurbitaceae, Fusarium oxysporum f.sp. niveum, identifikasi, layu

\begin{abstract}
Wilt disease of watermelon is an important disease in Indonesia, but determination of the causal agent has not been reported yet. Postulat Koch based approach was conducted to determine the pathogen causing wilt of watermelon from Karawang, West Java. Fungi associated with wilt symptoms were isolated from stem and root, then the fungal colonies were identified based on their morphological characters. Pathogenicity tests were performed using soil media and wet paper. Host range study involved other Cucurbitaceae plants, i.e. cucumber, melon and paria. Three species of Fusarium were successfully isolated from plants showing wilt symptom, i.e. F. oxysporum, F. solani, and F. semitectum. The fungus F. oxysporum consistently caused the most severe wilt symptom on watermelon, but developed no symptom on other tested cucurbits. The two fungi, F. solani and F. semitectum, caused necrotic on roots and stem of watermelon followed by wilting of the plant. The symptom was different than those of the initial symptoms from the field. Therefore it concluded that wilt symptom of watermelon is caused by Fusarium oxysporum f.sp. niveum.
\end{abstract}

Key words: Cucurbitaceae, Fusarium oxysporum f.sp. niveum, species identification, wilt

\footnotetext{
*Alamat penulis korespondensi: Departemen Proteksi Tanaman, Fakultas Pertanian, Institut Pertanian Bogor, Jalan Kamper Kampus Darmaga, Bogor 16680

Tel: 0251-8629364, Faks: 0251-8423048, Surel: efithpt@yahoo.com
} 


\section{PENDAHULUAN}

Tanaman semangka (Citrulus lanatus) dibudidayakan terutama untuk dimanfaatkan buahnya. Buah semangka digemari masyarakat karena mengandung banyak air, aromanya yang khas, rasanya manis, juga mengandung vitamin A. Biji semangka dapat diolah menjadi makanan ringan seperti kwaci, serta kulit buah semangka dapat diolah menjadi asinan atau acar. Budi daya tanaman semangka perlu dikembangkan seiring peningkatan pola makan dan kesadaran akan perlunya buahbuahan dalam pemenuhan gizi sehari-hari di Indonesia. Gangguan dalam teknik budi daya, termasuk masalah hama dan penyakit tanaman harus dapat dikendalikan karena dapat menjadi faktor pembatas dan kendala keberhasilan usaha budi dayanya.

Beberapa penyakit pada tanaman semangka yang dilaporkan di Amerika dan Eropa di antaranya adalah Colletotrichum lagenarium penyebab antraknosa (Caruso dan Kuć 1977), Pseudoperonospora cubensis penyebab embun bulu (Palti 1980), Fusarium oxysporum f.sp. niveum penyebab layu (Zhou dan Everts 2003), dan virus mosaik (Quemada et al. 1990). Penyakit layu Fusarium menjadi faktor pembatas utama produksi semangka di banyak wilayah karena menyebabkan kerusakan yang tinggi. Kerugian sebesar $20-30 \%$ produksi semangka terjadi di daerah endemik penyakit layu di China (Zhou et al. 2010). Patogen ini makin penting karena kemampuannya membentuk struktur istirahat (klamidospora) yang dapat bertahan lama sehingga tanah yang terinfestasi perlu diberakan dalam waktu lama (Suares-Estrella et al. 2004; Vankalaunakis dan Chalkias 2004).

Penyakit layu pada tanaman semangka di Indonesia banyak ditemukan di lapangan. Identifikasi jenis patogen dan perkembangan penyakit perlu diketahui sebagai tindakan awal dalam menentukan cara pengendalian penyakit yang tepat. Oleh karena itu, penelitian dilakukan untuk mengidentifikasi dan mempelajari kisaran inang patogen penyebab layu pada semangka.

\section{BAHAN DAN METODE}

\section{Isolasi dan Identifikasi Patogen}

Sampel tanaman semangka varietas 144 yang menunjukkan gejala layu dikumpulkan dari Kampung Kepuh, Desa Neglasari, Kecamatan Karawang, Kabupaten Karawang. Isolasi cendawan dilakukan dengan teknik tanam langsung bagian akar dan batang tanaman yang bergejala layu. Bagian ini dicuci dengan air mengalir, dipotong kecil berukuran $5 \mathrm{~mm} x$ $5 \mathrm{~mm}$, direndam dalam natrium hipoklorit $1 \%$ selama 2 menit. Potongan tersebut kemudian dibilas dengan air steril dan dikeringanginkan. Sampel yang telah kering ditanam pada medium potato dextrose agar (PDA). Cendawan dimurnikan dan dibuat biakan spora tunggal pada medium agar-agar air dan selanjutnya disimpan sebagai koleksi biakan murni untuk keperluan lanjut.

Cendawan diidentifikasi dan dicatat warna koloninya, diameter koloni umur 7 hari, bentuk fialid (monofialid atau polifialid), ada tidaknya klamidospora, rangkaian mikrokonidium, ada tidaknya sel kaki pada makrokonidium, panjang sel basal, jumlah sel dan ukuran makrokonidium - mikrokonidium (Booth 1971; Gerlach 1982; Watanabe 2001).

\section{Perbanyakan Cendawan Kandidat Patogen}

Cendawan diperbanyak menggunakan medium jerami. Sebanyak $200 \mathrm{~g}$ jerami yang dicuci bersih dan dikeringkan, dipotongpotong untuk kemudian dihaluskan. Jerami yang telah halus direndam dalam akuades selama 24 jam, diperas dan ditimbang ulang untuk mengetahui kadar airnya. Medium tumbuh ini disterilkan dalam autoklaf selama 20 menit pada suhu $121^{\circ} \mathrm{C}$. Medium diinokulasi dengan koloni kandidat patogen berdiameter $5 \mathrm{~mm}$ yang berumur 10 hari selama 2-3 minggu. Propagul cendawan yang tumbuh pada medium jerami dihitung menggunakan teknik pengenceran.

\section{Uji Patogenisitas Cendawan Kandidat Patogen}

Uji patogenisitas cendawan kandidat patogen dilakukan dengan 2 cara, yaitu metode tanah terinvestasi dan metode kertas 
merang dalam tabung reaksi. Uji tanah terinvestasi dilakukan dengan menanam benih semangka di dalam pot yang telah diisi dengan medium tumbuh yang terdiri atas campuran $2 \mathrm{~kg}$ tanah steril, $500 \mathrm{~g}$ pasir, dan $100 \mathrm{~g}$ biakan isolat dalam jerami. Sebagai kontrol medium tumbuh hanya diberikan $100 \mathrm{~g}$ jerami steril tanpa cendawan. Tiap perlakuan (jenis cendawan) terdiri atas 6 ulangan.

Tanaman dipelihara dan gejala diamati setiap hari sampai hari ke-30 setelah tanam. Cendawan yang menyebabkan gejala layu dan nekrotik diisolasi dengan metode teknik tanam langsung. Patogen penyebab penyakit dapat ditentukan jika hasil isolasi ini sama dengan patogen yang diinokulasikan.

Uji menggunakan metode kertas merang dilakukan dengan menumbuhkan benih semangka di dalam tabung reaksi yang berisi kertas merang lembap steril yang diinokulasi dengan koloni cendawan berdiameter $5 \mathrm{~mm}$. Sebagai kontrol, pada kertas saring tidak diberikan koloni cendawan. Gejala yang muncul diamati setiap hari selama 25 hari.

\section{Uji Kisaran Inang Cendawan Patogen}

Biakan murni isolat cendawan berumur 1-2 minggu pada medium PDA ditambah $10 \mathrm{~mL}$ air steril, diaduk dengan spatula untuk mendapatkan massa konidium cendawan. Konsentrasi akhir suspensi yang diinginkan ialah $10^{4}$ konidium $/ \mathrm{mL}$. Sebanyak $10 \mathrm{~mL}$ suspensi konidium dicampur dengan $150 \mathrm{~g}$ medium tanah dan pasir. Setelah 2 hari, benih tanaman uji ditanam pada medium tumbuh yang telah disiapkan. Sebagai kontrol, benih ditanam pada medium tanpa suspensi cendawan. Sebanyak 4 jenis tanaman (semangka, melon, paria, dan mentimun) digunakan dalam uji kisaran inang. Setiap perlakuan diulang 6 kali. Pengamatan dilakukan setiap hari sejak benih ditanam selama 25 hari.

\section{HASIL}

Gejala Penyakit di Lapangan dan Identifikasi

\section{Cendawan}

Gejala penyakit yang ditemui di lahan pertanaman semangka di Kampung Kepuh,
Desa Nagasari, Karawang sangat beragam, di antaranya ialah tanaman kerdil, layu, dan mengering serta buah semangka tidak berkembang. Informasi yang didapatkan dari petani setempat ialah sekitar $25 \%$ dari tanaman mereka menunjukkan gejala layu dan produksi berkurang. Bila batang tanaman yang bergejala layu dibelah, akan terlihat gejala nekrotik berwarna cokelat pada pembuluhnya yang menjadi ciri infeksi Fusarium. Tanaman bergejala layu ini diuji lebih lanjut di laboratorium.

Isolasi cendawan dari bagian yang bergejala didapatkan 3 spesies, yaitu Fusarium oxysporum, $F$. semitectum, dan $F$. solani (Gambar 1 dan 2). Cendawan F. oxysporum dicirikan oleh warna koloni ungu-putih, koloni berdiameter $6 \mathrm{~cm}$ setelah 7 hari pada medium PDA, monofialid, membentuk klamidospora. Klamidospora berbentuk bulat, dibentuk pada hifa dan konidium secara terminal atau interkaler. Mikrokonidium berlimpah, berbentuk oval, berukuran (3-12) x $(1.5 \times 3) \mu \mathrm{m}$. Makrokonidium hampir lurus, sel basal pendek, bersekat 3-7, dan berukuran (18-36) x $1.65 \mu \mathrm{m}$. Makrokonidium dan mikrokonidium terbentuk pada konidiofor yang pendek. Cendawan $F$. semitectum dicirikan dengan warna koloni putih-kuning dan koloni tua berubah menjadi cokelat pada medium PDA. Diameter koloni sepanjang $7.5 \mathrm{~cm}$ setelah berumur tujuh hari pada medium PDA, polifialid (polyblastic). Klamidospora terbentuk, berbentuk bulat, interkaler, dan berantai. Mikrokonidium jarang ditemukan, berbentuk oval berukuran (6-12) x $1.5 \mu \mathrm{m}$. Makrokonidium berbentuk seperti bulan sabit, bersekat 3-5, dan dengan ukuran (15-22.5) x $2.25 \mu \mathrm{m}$. Cendawan $F$. solani dicirikan dengan koloni berwarna putih dan yang sudah tua akan berwarna kuning tua, koloni berdiameter $7.5 \mathrm{~cm}$ setelah 7 hari pada medium PDA, monofialid, membentuk klamidospora. Klamidospora berbentuk bulat, dibentuk pada hifa dan konidium, terminal dan interkaler. Mikrokonidium berbentuk oval, berukuran (7.5-15) x $1.5 \mu \mathrm{m}$, makrokonidium bersekat 3-5, berukuran 30 × $3 \mu \mathrm{m}$. Makrokonidium dan mikrokonidium terbentuk pada konidiofor yang panjang. 


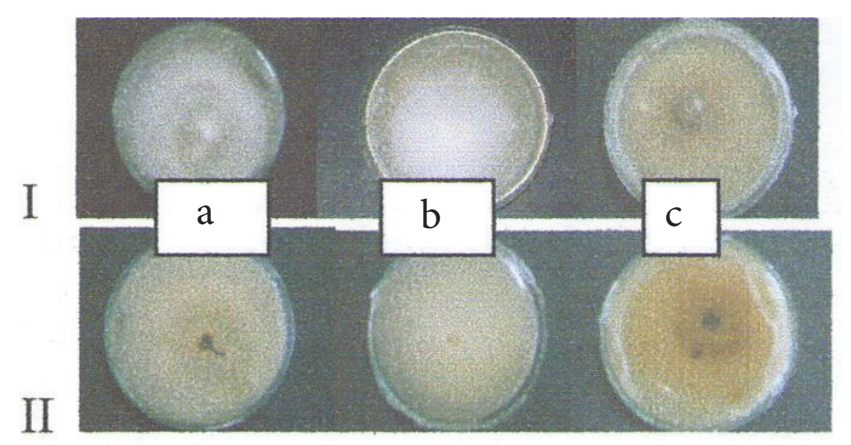

Gambar 1 Morfologi koloni: a, Fusarium oxysporum; b, F. solani; dan c, F. semitectum berumur 7 hari pada media PDA. I: permukaan atas, II: permukaan bawah.
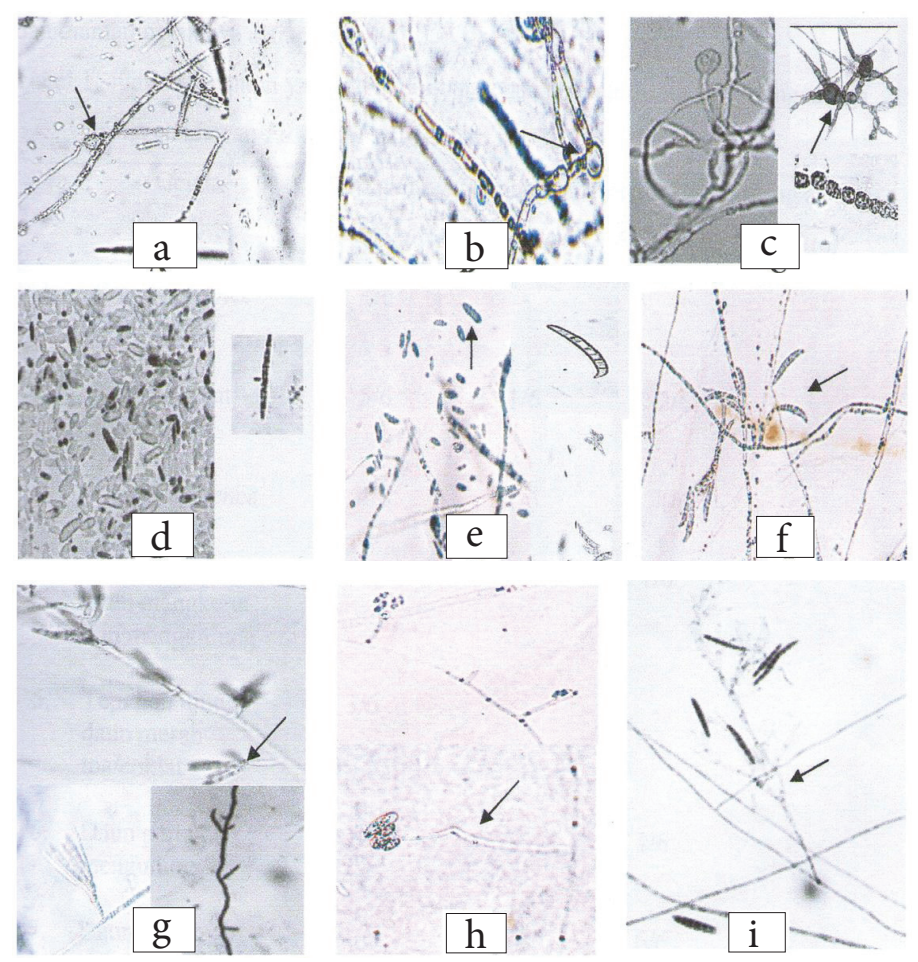

Gambar 2 Karakter morfologi mikroskopi dari Fusarium oxysporum (a, d, g), F. solani (b, e, h), dan F. semitectum (c, f, i). a,b,c, klamidospora; d,e,f, makrokonidium dan mikrokonidium; $\mathrm{g}, \mathrm{h}, \mathrm{i}$, konidiofor.

\section{Uji Patogenisitas Cendawan}

Tanaman semangka yang ditumbuhkan pada medium tanah yang terinvestasi masingmasing spesies Fusarium menunjukkan gejala yang bervariasi dengan masa inkubasi yang berbeda pula (Tabel 1). Gejala yang diakibatkan oleh $F$. oxysporum diawali dengan pertumbuhan tanaman yang kerdil pada hari ke-8 setelah tanam, batang berwarna pucat, menggenting dan rebah pada hari ke-10. Daun pertama menguning dimulai pada hari ke-9, kemudian gejala layu terjadi pada hari ke-17 setelah tanam (Gambar 3). Tanaman semangka yang ditumbuhkan pada medium terinfestasi $F$. semitectum menimbulkan gejala nekrotik cokelat pada batang dan daun layu pada hari ke-16 setelah tanam (Gambar 4a). Perlakuan media dengan $F$. solani menimbulkan gejala yang tidak terlalu parah bila dibandingkan dengan dua jenis Fusarium lainnya, yaitu nekrotik kecokelatan pada daun pertama yang terjadi pada hari ke-27 setelah tanam (Gambar 4b). Reisolasi cendawan yang dilakukan terhadap tanaman semangka yang menunjukkan gejala layu dan nekrotik menghasilkan cendawan yang sama, yaitu $F$. oxysporum, F. solani dan F. semitectum. 
Dalam tabung yang berisi kertas merang lembap, benih semangka diinokulasi dengan tiga spesies cendawan Fusarium secara terpisah memperlihatkan gejala yang berbedabeda. Pada hari ke-22 setelah inokulasi, $F$. oxysporum menginfeksi batang dan akar sehingga terjadi nekrosis berwarna cokelat, tetapi pada $F$. semitectum gejala terlihat lebih parah dibandingkan dengan $F$. oxysporum. Gejala berwarna cokelat tampak di seluruh bagian akar dan batang. Cendawan $F$. solani membentuk miselium putih yang menutupi permukaan seluruh tanaman, tetapi akar dan batang belum mengalami nekrosis. Setelah hari ke-24, ketiga spesies Fusarium tersebut membentuk miselium dan menutupi seluruh bagian tanaman. F. oxysporum menyebabkan nekrosis cokelat pada batang, perlahan-lahan batang membusuk, daun layu dan akhirnya tanaman mati dan kering. Gejala yang disebabkan oleh F. semitectum dan F. solani masih terbatas nekrotik pada batang dan akar,

Tabel 1 Jumlah tanaman yang menunjukkan gejala setelah diinokulasi dengan tiga jenis cendawan Fusarium hingga hari ke-30 dan masa inkubasi/kemunculan pertama kali tiap gejala

\begin{tabular}{llllllllrr}
\hline \multirow{2}{*}{ Gejala } & \multicolumn{2}{l}{ F. oxysporum } & \multicolumn{2}{c}{ F. solani } & \multicolumn{2}{c}{ F. semitectum } & \multicolumn{2}{c}{ Kontrol } \\
\cline { 2 - 10 } & Frek* & HST** & Frek & HST & Frek & HST & Frek & HST \\
\hline Pre-emergence damping off & $1 / 6$ & 7 & $0 / 6$ & - & $0 / 6$ & - & $0 / 6$ & - \\
Pertumbuhan terhambat & $5 / 6$ & $8-14$ & $1 / 6$ & 25 & $2 / 6$ & $14-23$ & $0 / 6$ & - \\
Post-emergence damping off & $4 / 6$ & $10-15$ & $1 / 6$ & 26 & $4 / 6$ & $15-25$ & $0 / 6$ & - \\
Layu & $1 / 6$ & $16-18$ & $5 / 6$ & $16-26$ & $2 / 6$ & $16-26$ & $1 / 6$ & 18 \\
\hline
\end{tabular}

*Frekuensi: perbandingan tanaman bergejala dari 6 ulangan

**HST: hari setelah tanam

-, tidak muncul gejala
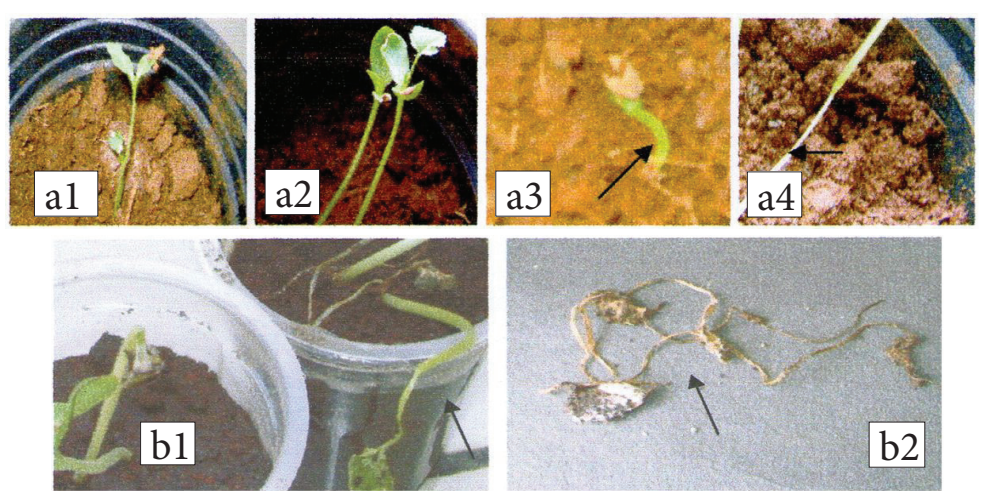

Gambar 3 Gejala penyakit yang terjadi pada tanaman semangka setelah inokulasi dengan Fusarium oxysporum pada perlakuan pertama (a) dan kedua (b). a1, a2, pertumbuhan terhambat; a3, a4, pemucatan dan kematian batang; b1, layu; b2, kematian seluruh tanaman.
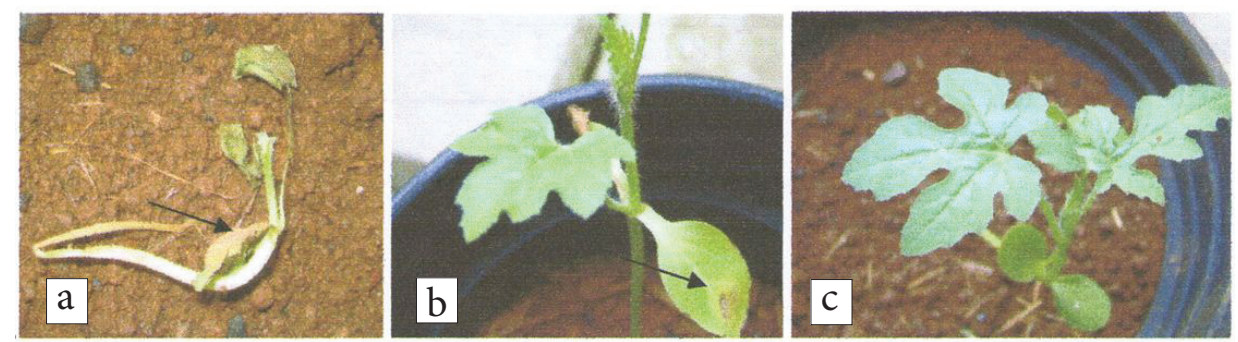

Gambar 4 Gejala penyakit yang terjadi pada tanaman semangka setelah inokulasi dengan Fusarium semitectum (a), Fusarium solani (b) dan kontrol (c). a, rebah kecambah; b, penguningan daun sebagai gejala awal nekrosis pada batang. 
daun belum terlihat layu. Tanaman kontrol tidak memperlihatkan adanya pembusukan pada semua bagian tanaman dan tetap berwarna hijau. Perkembangan gejala pada tanaman membuktikan bahwa ketiga isolat Fusarium merupakan patogen.

\section{Uji Kisaran Inang}

Cendawan $F$. oxysporum dan F. semitectum tidak menyebabkan gejala pada tanaman melon, mentimun, dan paria sampai hari ke-25 setelah inokulasi. Cendawan $F$. solani menyebabkan nekrotik pada tanaman mentimun pada hari ke-19 dan akhirnya tanaman layu, tetapi tidak menyebabkan gejala pada tanaman melon dan paria (Tabel 2). Gejala pada tanaman semangka hanya muncul pada perlakuan dengan $F$. oxysporum berupa gejala layu yang sangat parah dan akhirnya tanaman ditutupi oleh miselium cendawan berwarna putih. F. solani dan F. semitectum tidak menyebabkan gejala penyakit pada tanaman semangka, tidak seperti pada uji patogenisitas sebelumnya.

\section{PEMBAHASAN}

Penentuan penyebab layu pada semangka dilakukan dengan uji biologi mengikuti Postulat Koch. Identifikasi cendawan yang berhasil diisolasi dari tanaman ialah $F$. oxysporum, F. semitectum, dan $F$. solani. Hasil uji patogenisitas pada semangka yang dilakukan sebanyak tiga kali menunjukkan bahwa $F$. oxysporum secara konsisten menginfeksi dan menimbulkan gejala layu pada semangka, sedangkan $F$. semitectum dan F. solani menimbulkan gejala pada uji pertama dan ketiga. Konsentrasi cendawan uji cukup tinggi dalam medium tumbuh tanaman pada pengujian pertama, sekitar $5 \mathrm{x}$ $10^{5}$ propagul $\mathrm{g}^{-1}$ medium jerami atau $2 \times 10^{4}$ propagul $\mathrm{g}^{-1}$ medium tumbuh; sedangkan pada pengujian kedua, konsentrasinya $10^{4}$ spora $\mathrm{mL}^{-1}$ suspensi atau hanya $6.7 \times 10^{2}$ spora $\mathrm{g}^{-1}$ medium tumbuh tanaman. Konsentrasi ini memimik kondisi alami di lapangan, ketika konsentrasi cendawan di dalam tanah bekas pertanaman Cucurbitaceae sekitar $10^{2} \mathrm{cfu} \mathrm{g}^{-1}$ tanah (Nordahliawate 2012). Selain karena konsentrasi cendawan yang rendah, pada uji kedua digunakan spora sebagai sumber inokulum sehingga diduga spora memiliki keefektifan yang rendah dalam menginfeksi tanaman. Walaupun demikian, dari hasil ini dapat disimpulkan bahwa ketiga spesies Fusarium tersebut adalah patogen

Gejala yang muncul karena inokulasi tanaman semangka dengan $F$. oxysporum ialah rebah kecambah, kerdil, penguningan daun diikuti oleh layu. Rebah kecambah terjadi pada pengujian pertama karena populasi patogen yang cukup tinggi sehingga dengan mudah mematikan benih yang akan berkecambah ataupun menyerang bibit yang baru saja tumbuh. Pertumbuhan tanaman terhambat

Tabel 2 Uji kisaran inang Fusarium spp. asal semangka sampai hari ke-25

\begin{tabular}{lcccccc}
\hline \multirow{2}{*}{ Gejala } & \multicolumn{2}{c}{ F. oxysporum } & \multicolumn{2}{c}{ F. solani } & \multicolumn{2}{c}{ F. semitectum } \\
\cline { 2 - 7 } & Frek* & HST** & Frek & HST & Frek & HST \\
\hline $\begin{array}{l}\text { Semangka } \\
\text { Pertumbuhan terhambat }\end{array}$ & $2 / 6$ & 15 & $0 / 6$ & - & $0 / 6$ & - \\
$\quad$ Layu & $3 / 6$ & 17 & $0 / 6$ & - & $0 / 6$ & - \\
Mentimun & & & & & & \\
$\quad$ Layu & $0 / 6$ & - & $3 / 6$ & 19 & $0 / 6$ & - \\
Melon & $0 / 6$ & - & $0 / 6$ & - & $0 / 6$ & - \\
Paria & $0 / 6$ & - & $0 / 6$ & - & $0 / 6$ & - \\
Kontrol & $0 / 6$ & - & $0 / 6$ & - & $0 / 6$ & - \\
\hline
\end{tabular}

*Frekuensi: perbandingan tanaman bergejala dari 6 ulangan

**HST: hari setelah tanam, pertama kali muncul gejala

-, tidak muncul gejala 
Budiastuti et al.

dan menjadi kerdil karena kerusakan pada akar atau pada jaringan pembuluh tanaman. Penguningan pada daun terjadi karena cendawan memproduksi toksin di parenkim dan xilem yang lalu dibawa ke daun yang merusak membran sel daun. Tanaman akhirnya layu oleh karena rusaknya pembuluh xilem sehingga tidak mampu mengangkut air dan nutrisi yang dibutuhkan tanaman.

Inokulasi tanaman semangka dengan $F$. semitectum dan $F$. solani menghasilkan gejala nekrotik, batang berwarna cokelat dan akhirnya tanaman layu. Menurut Zitter et al. (1998) kedua spesies cendawan ini menyebabkan lesio internal yang berwarna cokelat pada bagian yang diinfeksi. $F$. semitectum sebenarnya merupakan patogen sekunder, jarang berperanan sebagai patogen bila sendiri (Booth 1971). F. solani dapat menyebabkan gejala layu pada Cucurbitaceae yang sering dikacaukan dengan gejala layu yang disebabkan oleh F. oxysporum. Perbedaan keduanya ialah $F$. solani tidak bersifat sistemik seperti halnya $F$. oxysporum yang lebih dikenal sebagai penyebab penyakit jaringan pembuluh (Snyder dan Hansen 1941; Cumagun et al. 2010). F. solani f.sp. cucurbitae diketahui menginfeksi Cucurbitaceae secara umum, menyebabkan busuk buah dan pangkal batang tanaman (Boughalleb dan El Mahjoub 2006).

Berdasarkan hasil uji kisaran inang pada melon, mentimun, paria, dan semangka diketahui bahwa spesifikasi $F$. oxysporum cukup tinggi pada semangka sehingga dapat disimpulkan bahwa cendawan tersebut adalah F. oxysporum f.sp. niveum. Cendawan ini hanya menyerang tanaman semangka dan tidak menyerang Cucurbitaceae lainnya (Snyder dan Hansen 1941). Forma spesiales didefenisikan sebagai cendawan (khususnya $F$. oxysporum) yang hanya menyerang satu spesies tanaman. F. oxysporum f.sp. niveum terdiri atas tiga ras, yaitu ras 0, 1, dan 2 (Egel et al. 2005; Lin et al. 2009; Zhou et al. 2010). Tiap kultivar semangka memiliki ketahanan yang bervariasi terhadap ras 0 dan 1 dari $F$. oxysporum f.sp. niveum, namun hingga saat ini belum ada yang tahan terhadap ras 2 (Wechter et al. 2012).

\section{UCAPAN TERIMA KASIH}

Penelitian ini dibiayai oleh DIKTI melalui Proyek Hibah Bersaing tahun 2006 dengan nomor kontrak 317/SP3/PP/DP2M/II/2006.

\section{DAFTAR PUSTAKA}

Booth C. 1971. The Genus Fusarium. Surrey (UK): CMI.

Boughalleb N, El Mahjoub M. 2006. In vitro determination of Fusarium spp. infection on watermelon seeds and their localization. Pant Pathol J. 5(2)178-182. doi: 10.3923/ ppj.2006.178.182.

Caruso, FL, Kuć J. 1977. Protection of watermelon and muskmelon against Colletotrichum lagenarium by Colletotrichum lagenarium. Phytopathology. 67:1285-1289.

Cumagun CJR, Aguirre JA, Relevante CA, Balatero CH. 2010. Pathogenicity and aggressiveness of Fusarium oxysporum Schl. in bottle gourd and bitter gourd. Plant Protect Sci. 46(2):51-58.

Egel DS, Harikrishnan R, Martyn R. 2005. First report of Fusarium oxysporum f.sp. niveum race 2 as causal agent of Fusarium wilt of watermelon in Indiana. Plant Dis. 89(1):108. doi: 10.1094/PD-89-0108A.

Gerlach W, Nirenberg H. 1982. The Genus Fusarium: a Pictorial Atlas. Berlin (DE): Institut fur Microbiologie.

Lin YH, Chen KS, Liou TD, Huang JW, Chang PFL. 2009. Development of a molecular method for rapid differentiation of watermelon lines resistant to Fusarium oxysporum f.sp. niveum. Bot Stud. 50:273280.

Nordahliawate S, Izzati NA, Azlin N, Baharudin S. 2012. Diversity of Fusarium species isolated from soil cultivated with cucurbits within east cost, Peninsular Malaysia. Pertanika J Trop Agric Sci. 35(2):381-386.

Palti JY. 1980. Downy mildew of cucurbits (Pseudoperonospora cubensis): the fungus and its hosts, distribution, epidemiology and control. Phytoparasitica. 8(2):109147. doi: 10.1007/BF02994506. 
Quemada H, Sieu LC, Siemieniak DR, Wechter WP, Kousik C, McMillan M, Levi Gonsalves D, Slightom JL. 1990. Watermelon mosaic virus II and zucchini yellow mosaic virus: cloning of 3'-terminal regions, nucleotide sequences, and phylogenetic comparisons. J Gen Virol. 71:1451-1460.

Snyder WC, Hansen HN. 1941. The species concept in Fusarium with reference to Section Martiella. Am J Bot. 28(9):738742.

Suarez-Estrella F, Vargas-Garcia MC, Lopez MJ, Moreno J. 2004. Survival of Fusarium oxysporum f.sp. melonis on plant waste. Crop Protection. 23(2):127-133. doi: 10.1016/j.cropro.2003.07.006.

Vakalounakis DJ, Chalkias J. 2004. Survival of Fusarium oxysporum f.sp. radiciscucumerinum in soil. Crop Protection. 23(9):871-873. doi: /10.1016/j.cropro.2004. 01.011 .

Watanabe T. 2001. Pictorial Atlas of Soil and Seed Fungi: Morphologies of Cultures Fungi and Key to Species. Boca Raton (US): Crc Pr.

A. 2012. Identification of resistance to Fusarium oxysporum f.sp. niveum race 2 in Citrulus lanatus var. citroides plant introduction. HortScience. 47(3):334-338.

Zhou XG, Everts KL. 2003. Races and inoculum density of Fusarium oxysporum f.sp. niveum in commercial watermelon fields in Maryland and Delaware. Plant Dis. 87(6):692-698. doi: 10.1094/PDIS.2003. 87.6.692.

Zhou XG, Everts KL, Bruton BD. 2010. Race 3, a new and highly virulent race of Fusarium oxysporum f.sp. niveum causing Fusarium wilt in watermelon. Plant Dis. 94(1):92-98. doi: 10.1094/PDIS-94-1-0092. Zitter TA, Hopkins DL, Thomas CE. 1998. Compendium of Cucurbit Diseases. Minnesota (US): APS Press. 